Nutr. Metab. 1980;24:I-VI

\title{
Contents, Vol. 24, 1980
}

\section{Nutrition and Metabolism}

Journal of Nutrition, Metabolic Diseases and Dietetics

Founded 1959 as 'Nutritio et Dieta' by E. Azerad, H. Kapp and J. Trémolières Former Main

Editor: A. Wretlind (1961-1969)

Main Editor

N. Zöllner, Munich

Associate Editors

E.M. Widdowson, Cambridge G. Wolfram, Munich

Editorial Board

W. Auerswald, Vienna H.D. Cremer, Giessen G. Debry, Nancy J.W.T. Dickerson, Guildford F. Falkner, Yellow Springs,

Ohio R. Gitzelmann, Zurich L. Hambraeus, Uppsala

G. Hartmann, Chur

C. den Hartog, Rijswijk K. Hellström, Stockholm S. Heyden, Durham, N.C. F.A. Hommes,

Groningen B. Jacotot, Créteil D.E.M. Lawson, Cambridge I. Macdonald, London H.K. Mangold, Münster

K.R. Norum, Oslo P.R. Payne, London G. Schlierf, Heidelberg J.C. Somogyi, Zurich M.A.

Spadoni, Roma A.J. Vergroesen,

Vlaardingen-Duiven A. Wretlind, Emeryville, C.A.

S.Karger $\cdot$ Basel $\cdot$ München $\cdot$ Paris $\cdot$ London $\cdot$ New York $\cdot$ Sydney

Drug Dosage

The authors and the publisher have exerted every effort to ensure that drug selection and dosage set forth in this text are in accord with current recommendations and practice at the time of publication. However, in view of ongoing research, changes in government regulations, and the constant flow of information relating to drug therapy and drug reactions, the reader is urged to check the package insert for each drug for any change in indications and dosage and for added warnings and precautions. This is particularly important when the recommended agent is a new and/or infrequently employed drug.

All rights reserved.

No part of this publication may be translated into other languages, reproduced or utilized in any form or by any means, electronic or mechanical, including photocopying, recording, microcopying, or by any information storage and retrieval system, without permission in writing from the publisher.

S. Karger AG, P.O. Box, CH-4009 Basel (Switzerland) Printed in Switzerland by Thür AG

Offsetdruck, Pratteln

Contents

No. 1

Energiebilanzversuche mit einer kohlenhydratfreien Protein-Fett-Diät

Kirchgessner, M. und Müller, H.L 1 
Utilization of Protein at Sub-Maintenance Energy Intakes

Naismith, D.J. and Holdsworth, M.D 13

Assessment of Nutritional Status in Adult Hospitalized Patients

Tanphaichitr, V.; Kulapongse, S., and Komindr, S 24

Supplemental Dietary Carnitine and Lipid Metabolism in Exercising Rats

Askew, E.W.; Dohm, G.L.; Weiser, P.C.; Huston, R.L., and Doub, W.H., Jr. . 32 Effect of

Undernutrition on Lipid Metabolism of Brain. In vivo Incorporation of Labelled Acetate and

Palmitate into Lipids

Chauhan, S.†; Jailkhani, R., and Subrahmanyam, D 43

Dietary Management of Chronic Renal Failure with Oral Amino Acids

Lee, H.A.; Talbot, S.; Rowlands, A., and Jackson, M.A 50

Book Review 64

No. 2

Bakteriologische Aspekte des Warmhaltens von frisch zubereitetem Spinat. Zusam-menhang zwischen der Keimzahl und der Nitratreduktion

Bomar, M.T. und Wedler, A.-M 65

Influence du taux de calories lipidiques de la ration alimentaire sur les effets nutri-tionnels de

Toxythioquinox chez le rat

Carrera, G.; Mitjavila, S.; Delvolve, N. et Derache, R

76

Levels of Minerals, Lipoproteins and Lipids in Plasma, Liver and Tibia from Female Rats Fed on

a Zinc-Supplemented Rapeseed Protein Diet

Eklund, A 91

Studies on the Extent of Dietary Fiber Intake in West Germany

Kasper, H.; Rabast, U., and Ehl, M 102

The Energy Requirement for Growth. A Reevaluation

Hommes, F.A • 110

$\mathrm{Na}+, \mathrm{K}+-\mathrm{ATPase}$ in Developing Rat Brain during Undernutrition

Mishra, O.P. and Shankar, R 114

Contents IV

Tissue Distribution of 14C-Labelled Triolein in a Soybean Oil Emulsion. An Autoradiographic

Study in Rat and Mouse

Appelgren, L.E. and Rössner, S 122

Book Reviews 135

No. 3

Intervention Study in High School Students with Elevated Blood Pressures. Dietary Experiment with Polyunsaturated Fatty Acids

Stern, B.; Heyden, S.; Miller, D.; Latham, G.; Klimas, A., and Pilkington, K. 137 Red Blood Cell Fatty Acid Composition in a Sample of Italian Middle-Aged Men on Free Diet

Angelico, F.; Amodeo, P.; Borgogelli, C; Cantafora, A.; Montali, A., and

Ricci, G 148

Lysosomal Acid Phosphatase Decrease in Nutritional Encephalopathy in Chicks

Dror, Y. and Budowski, P 154

The Effect of Various Cholecalciferol-Related Substances on the Biosynthesis of the

Cholecalciferol-Dependent Calcium-Binding Protein in the Small Intestine of the Rachitic Chick and Its Relation to Rickets

Jones, L.T.; Cruickshank, E.M., and Kodicek, E 161 
Plasma Glucose and Insulin Responses to Orally Administered Carbohydrate-Rich Foodstuffs Vaaler, S.; Hanssen, K.F., and Aagenæs, 0168

Effect of Folate Supplementation and Malaria on the Folate Content of Human Milk

Osifo, B.O.A. and Onifade, A176

Effect of Dietary Sucrose in Humans on Blood Uric Acid, Phosphorus, Fructose, and Lactic Acid Responses to a Sucrose Load

Solyst, J.T.; Michaelis, O.E. IV.; Reiser, S.; Ellwood, K.C., and Prather, E.S. . 182 Effects of Undernutrition on Nucleic Acid Synthesis in Neuronal and Glial Cells from Different Regions of Developing Rat Brain

Giuffrida, A.M.; Hamberger, A.; Serra, I., and Geremia, E 189

Effect of Feeding Different Levels of Mustard Oil in Monkeys

Shenolikar, I.S. and Tilak, T.B.G 199

No. 4

Oral and Parenteral Nutrition with L- Valine: Mode of Action

Riederer, P.; Jellinger, K.; Kleinberger, G., and Weiser, M 209

Spontaneous Activity and Food Requirements for Maintenance and for Growth in the

Genetically Obese Zucker Rat

Haberey, P.; Bach, A.; Schaefer, A., and Piquard, F 218

Contents

$\mathrm{V}$

Lecithin Supplementation in Healthy Volunteers. Effects on Cholesterol Esterification and Plasma, and Bile Lipids

Cobb, M.; Turkki, P.; Linscheer, W., and Raheja, K 228

Effects of Timing on Energy Expenditure during Rest and Exercise in Obese Women

Zahorska-Markiewicz, B 238

Absorption and Retention of Magnesium and Some Trace Elements by Man from Typical Indian

Diets

Rao, C.N. and Rao, B.S.N 244

Ineffectiveness of Testosterone and FSH in Maintaining the Vitamin A Deficient Rat Testis

Catignani, G.L. and Bieri, J.G 255

Lipid and Carbohydrate Metabolism in Uremia. Influence of Treatment with Protein-Reduced

Diet and Essential Amino Acids

Attman, P.-O. and Gustafson, A 261

No. 5

Effect of Calcium and Copper on Zinc Absoption in the Rat

Adham, N.F. and Song, M.K 281

Über die cholesterinsenkende Wirkung der einzelligen Grünalge Scenedesmus aca-tus 276-3a. I.

Wirkung von walzengetrockneter Algensubstanz

Rolle, I. und Pabst, W 291

Über die cholesterinsenkende Wirkung der einzelligen Grünalge Scenedesmus acu-tus 276-3a. II.

Wirkung von Algenfraktionen

Rolle, I. und Pabst, W 302

Influence of Cholecalciferol on Tissue Zinc Homeostasis in the Rat

Chausmer, A.B.; Ward, G., and Zears, R 314

Acceleration of Ethanol Elimination with Fructose in Man

Sprandel, U.; Tröger, H.-D.; Liebhardt, E.W., and Zöllner, N 
Selenium in Premature Infants

Amin, S.; Chen, S.Y.; Collipp, P.J.; Castro-Magana, M.; Maddaiah, V.T., and

Klein, S.W 331

No. 6

Editorial

Information from the Publisher · Communique de Гéditeur a Verlagsmitteilung . . 341

Original Paper

Einfluss verschiedener Spurenelemente auf die tryptische Hydrolyse

Wieninger-Rustenmeyer, R.; Kirchgessner, M., and Steinhart, H. (Freising-

Weihenstephan) $\quad 343$

Contents VI

Studies on Interrelationship between Vitamins E and B-Complex

Nadiger, H.A 352

Body Lipids of Guinea Pigs Exposed to Different Dietary Fats from Mid-Gestation to 3 Months of Age. V. The Fatty Acid Composition of Brain Lipids at Birth

Pavey, D.E. and Widdowson, E.M 357

Effets de $\Gamma$ administration de precurseurs metaboliques du propionate à des rats ca-rencés en biotine

Cherruau, B.; Mangeot, M.; Demelier, J.F.; Charpentier, C; Pelletier, C. et

Lemonnier, A 367

'Post-Coronary' Rehabilitation, Body Composition, and Recurrent Infarction. An Analysis of

Data from the Ontario Exercise-Heart Collaborative Study

Shephard, R.J 383

Influences of Dietary Fats on Coronary Flow Rate and Left Ventricular Work of the Isolated Rat

Heart: Sunflower Seed Oil versus Lard

De Deckere, E.A.M. and Ten Hoor. F

396

Urea Synthesis by Perfused Rat Liver in Experimental Uremia

Perez, G.; Rietberg, B.; Owens, B.; Parker, T,; Obaya,H., and Schiff, E. . . . 409 L-Dopa

Competes with Tyrosine and Tryptophan for Human Brain Uptake

Riederer, P 417

Erratum $\quad 424$

Author Index 425

Subject Index 427

Supplement 1

Lipids and Lipoproteins

Proceedings of a Scientific Symposium of the International Federation of Margarine

Associations, Brussels, May 17-18, 1979

Guest Editor: M. Fondu, Brussels 